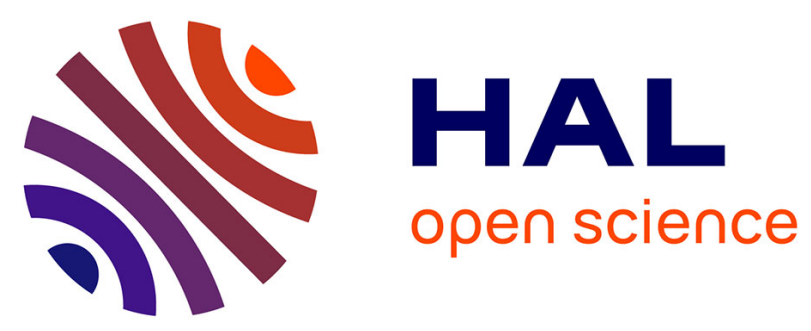

\title{
Vehicle-assisted ligature decapitation: A case report and a review of the literature
}

\author{
E. Marchand, V. Mesli, E. Le Garff, J. Pollard, A. Bécart, V. Hédouin, D. \\ Gosset
}

\section{- To cite this version:}

E. Marchand, V. Mesli, E. Le Garff, J. Pollard, A. Bécart, et al.. Vehicle-assisted ligature decapitation: A case report and a review of the literature. Journal of Forensic and Legal Medicine, 2019, 65, pp.119 - 123. 10.1016/j.jflm.2019.05.015 . hal-03485706

\section{HAL Id: hal-03485706 https://hal.science/hal-03485706}

Submitted on 20 Dec 2021

HAL is a multi-disciplinary open access archive for the deposit and dissemination of scientific research documents, whether they are published or not. The documents may come from teaching and research institutions in France or abroad, or from public or private research centers.
L'archive ouverte pluridisciplinaire HAL, est destinée au dépôt et à la diffusion de documents scientifiques de niveau recherche, publiés ou non, émanant des établissements d'enseignement et de recherche français ou étrangers, des laboratoires publics ou privés.

\section{다)(1) $(5$}

Distributed under a Creative Commons Attribution - NonCommerciall 4.0 International 


\section{Vehicle-assisted ligature decapitation: a case report and a review of the literature}

E. Marchand ${ }^{*, * *}$, V. Mesli ${ }^{* * * *}$, E. Le Garff ${ }^{* * * *}, J_{.}$Pollard ${ }^{* *}$, A. Bécart ${ }^{* * * *}$, V. Hédouin ${ }^{*, * *}$, D. Gosset ${ }^{* * * *}$

* Univ. Lille, EA 7367 - UTML - Unité de Taphonomie Médico-Légale, F-59000 Lille, France

** CHU Lille, Service de Médecine Légale, F-59000, France

Corresponding Author:

Dr Elodie MARCHAND (M.D.)

ORCID n ${ }^{\circ}$ : orcid.org/0000-0003-0176-0151

Univ. Lille, EA 7367 - UTML - Unité de Taphonomie Médico-Légale, F-59000 Lille, France

CHU Lille, Service de Médecine Légale, F-59000, France

Tel: +33320623501

Fax: +33320623512

Mail: e.marchand06@gmail.com

\section{Acknowledgment}

The authors thank the pathology institute of Lille University Hospital. 


\title{
Vehicle-assisted ligature decapitation: a case report and a review of the literature
}

\begin{abstract}
Decapitation resulting by vehicle-assisted ligature strangulation is a suicide method rarely described in the literature. The lesions observed at autopsy have a common morphology with to those found in post-hanging decapitation. They depend on the force applied by the acceleration of the vehicle, the slope of the road and the characteristics of the link used. They can also mimic a stabbing homicide. We report the case of a 43-year-old man who used a long steel rope, attached between his neck and a streetlight, and started his vehicle, causing a complete decapitation. The results of the autopsy provided information on the morphology of the cervical lesions, but also on the causes of death. In spite of decapitation, the histological examination of the organs confirmed the presence of asphyxiation process by a mechanical origin that occurred before decapitation.
\end{abstract}

Keywords: Vehicle-assisted suicide; Decapitation; Ligature strangulation; Forensic science 


\section{Introduction}

In forensic practice, decapitation is most commonly encountered in vehicle crashes, homicides or post-mortem dismemberment $[1,2]$. In the literature, a few cases of decapitation have been described in a suicidal context. In the majority of cases, the decapitation is the result of traumatic rail injury [3-5] or post-hanging [6-8]. However, some cases of decapitation by vehicle-assisted ligature strangulation have also been reported [1,9]. In the cases using a ligature, the distinction with a homicide can be difficult, because the aspect of the wounds can be similar $[1,7]$.

We present morphological characteristics and death mechanisms from a case of decapitation secondary to strangulation by vehicle-assisted ligature. In association with a review of the literature, we propose some elements of distinction between suicidal and homicidal decapitation.

\section{Case report}

The decapitated body of a 43-year-old man, measuring $175 \mathrm{~cm}$ and weighing $98 \mathrm{~kg}$, was found alone sat driver's side of a vehicle, engine running, stuck in a field below a parking lot. His seatbelt fastened, the doors closed, the left rear window broken. Upstream of the vehicle, a barrier had been destroyed. With these elements, the police feared a terrorist act. After opening of the vehicle, the man's head was found in front of the passenger's seat and a great amount of blood was present on the driver's seat and clothing of the victim (figure 1). Several empty bottles of alcohol were also present in the vehicle. The first gear was engaged and the man's foot was press on the accelerator pedal. About a hundred meters from the vehicle, a steel rope, of a diameter 0,5 centimeters, was discovered attached to a street light on parking lot (figure 1). Concerning his medical history, he was depressive and had made a suicide attempt.

At the external examination we observed signs of asphyxia with the presence of discrete cyanosis of face and nails as well as a conjunctiva hemorrhage. At autopsy, the examination of the cervical wound showed a clear-cut and a hemorrhagic infiltration of edges, slightly abraded at its rear part of the neck (figure 2). At the anterior part of the neck, the severance plane passed between the hyoid bone and the thyroid cartilage and at the posterior part, between the third and fourth cervical vertebra. We observed a complete section of the cervical spine passing through the third intervertebral disc, associated with a fracture of the spinous process and the left pedicle of the third cervical vertebra. After an edge-to-edge, both parts of the cervical spine were perfectly articulated (figure 3). The dissection of the cutaneous and muscular levels revealed a diffuse hemorrhagic infiltration of the cervical region of the severance level. The left upper horn of the thyroid cartilage was completely cut with an infiltrated section. The hyoid bone and the cricoid cartilage were intact. The carotid arteries were sectioned, with hemorrhagic infiltration and abrasion of the edges (figure 4). The pleural cavities were dry, without effusion or adhesion. The trachea and the bronchi contained non-obstructive blood clots. The right and left lungs weighed $658 \mathrm{~g}$ and $579 \mathrm{~g}$ respectively and were edematous and congestive, as was the brain. No other traumatic lesions were found. The other thoracic and the abdominal organs appeared pale and bloodless. 
The pathological examination showed the signs of an acute asphyxia associating an intense pulmonary alveolar edema with marked vascular congestion. It was also noted a heterogeneous ventilation of the pulmonary parenchyma alternating condensed and distended alveoli, with a rupture of inter alveolar septa and pleural emphysema, which indicate a mechanical participation in asphyxia. The examination of the carotids revealed an adventitial hemorrhagic infiltration with fresh blood cells and rare inflammatory elements.

The toxicological analyses (blood, urine, bile, stomach content and vitreous humor) were not required by justice.

\section{Discussion}

Decapitation consists of the separation of the head of the body [10]. It is historically associated with the judiciary's executions, with using a sword or axe in medieval England or a guillotine during the French Revolution [2,11]. More recently, this method was used by the cartels of drug, in armed conflicts and terrorist acts [2,10]. In forensic medicine, the cases of decapitation are rather rare. Various centers have collected the cases of decapitation in their activity, without distinction of origin, and have recorded few cases; the study of Rao found 26 cases per 3907 autopsies [10], that of Tsokos 10 per 7681 [3] and those of Kumral and Byard respectively 19 per 36270 [12] and 20 per 16589 [4]. The origin of the decapitation (accident, homicide and suicide) would be in association with the socio-economic and cultural local influence. These are mainly vehicle accidents $[1,2]$ where the authors attribute decapitation to a mechanism of cervical hyperextension and inertia by an impact of the face against an unmovable object (barrier or crossbar for example) [4,13]. The accidents are observed at high kinetics in unbelt passengers ejected from the vehicle $[14,15]$. For motorcyclists, decapitation would be due to the application by the helmet of a force opposed to that of the neck during the impact $[16,17]$. The decapitation in a suicidal context would represent less than $1 \%$ of the suicides [4]. In particular, there are suicides on the railway where the individual puts his head directly on a rail [3] or cases of decapitation by the use of an artisanal guillotine [18].

Decapitation resulting by vehicle-assisted ligature strangulation uses a ligature pulled between the neck of the driver and a stationary object, associated with the start-up of the vehicle $[1,19,20]$. The cases described in literature suggested a young or adult male predominance. Indeed, the men are more inclined to use violent suicide methods and young or adult people would use it for its accessibility and effectiveness [4]. In this kind of strangulation, it is the kinetic factors and the physical characteristics of the ligature used, which determine the occurrence of a complete decapitation. This method requires a fast acceleration of the vehicle and the use of strong and inelastic ligature $[1,3,4]$ like cable steel or nylon twisted rope. Our case associated these two elements, since the man had used a steel rope and that the presence of his foot on the accelerator, as well as the destruction of a barrier on the way, suggested important kinetics of the vehicle moving. If the vehicle is positioned on a steep slope, even in the absence of acceleration, decapitation can occur [21]. Finally, low driving speed, broken rope and low slope, can lead to an incomplete decapitation or ligature strangulation like a homicide [22,23].

The lesions observed have a common morphology (table 1). The wounds have a clear-cut and a hemorrhagic infiltration of edges with a peripheral abrasion. The severance plane is most 
generally located above the fourth cervical vertebra. These lesions are similar to those observed in post-hanging decapitation, although differences exist (table 2). In both situations, we observe the presence of circumferential band-like neck abrasion, corresponding to the local friction of the ligature used $[1,3,7,19,21]$. Fractures of the larynx (hyoid bone or upper horns of the thyroid cartilage) are mainly found in decapitation post-hanging [7,22] in relation to traction and oscillation [1]. For decapitations resulting by vehicle-assisted ligature strangulation, if the severance plane is located at the level of the larynx, we can be observed fractures of the thyroid cartilage or the hyoid bone [1], or as in our case, the complete sections of thyroid horn [2]. The severance plan is rather located between the third and the fourth cervical vertebra [1], unlike the decapitations post-hanging, where the section is located higher on the cervical spine, preferentially between the first and the second vertebra $[7,26]$. This difference is explained by the application of a radial force of shearing, rather than an axial force of traction $[7,26]$. The application of this radial force causes the cervical lesions and this one depends on the acceleration of the vehicle. It is difficult to measure due to the involvement of other factors related to the ligature used and the mobility of the victim in the driver compartment, including the wearing or not of the seatbelt [2]. We spoke of accidental decapitation in motorcyclists related to the strength of helmet. It was also described three cases of strangulation with decapitation related to a cable or the chain of the vehicle $[27,28]$. In this case the lesions observed are similar to those which we described, by the same mechanism by the application of a radial force on the neck. We find circumferential cervical abrasion; on the other hand, the severance plan can be located at height of the first cervical vertebra or much lower of the fourth to the sixth vertebra.

It should not be forgotten that decapitation can be related to post-mortem dismemberment. This method is used to make it difficult the identification of a body or to keep a trophy $[10,12]$. Rarely, post-mortem decapitation can be linked to the action of an animal. The wounds are located on unclothed areas of the body and we can observe puncture lesions inflicted by canine teeth or claws [29]. The presence of blood on the scene of the discovery and the exsanguination of the organs are indicators, as we noted in our case. But to eliminate post-mortem decapitation, the presence of vital reaction in autopsy and histology is essential [7,10,26]. It is objectified, as in our case, by the presence of an infiltration of tissues and cervical vessels, as well as fractures. However, the absence of hemorrhagic infiltration of tissues as a conclusion of post-mortem decapitation can be misleading if the dismemberment occurs in the minutes following the death [12]. Other vital reactions have also been described in autopsy, such as blood inhalation, as we have seen, and subendocardial hemorrhages. In CT-scan we can observe tissue emphysema, pneumomediastinum, and air embolism. They are mainly observed in post hanging decapitations $[3,7,10]$.

On the other hand, it can be more difficult to carry out a distinction with a homicide. Like the rope used in our case, if the diameter of the ligature used is too small, it can evoke the use of a cutting instrument. The lesions described in the literature provide guidance (table 2). The wounds have clear edges, sometimes contused, but without peripheral abrasion [12]. The description of a cutting irregularity of the underlying tissues will be able to make it possible to be oriented to a decapitation caused by a ligature [2]. In cases of homicides per decapitation, the severance plane is often located high, between the first and second cervical vertebra or between the second and third cervical vertebra. There is little lesion of the larynx and the 
cervical injuries is often associated other wounds on the body [7,10,12,21]. The presence of self-injury lesions or, as in our case, a documented depression, is also an element of orientation for a suicidal origin [3].

Finally, in decapitation resulting by vehicle-assisted ligature strangulation, although death is attributed to arterial vascular and neurological lesions related to decapitation, asphyxia occupies an important place in fatal determinism, as we observed. The asphyxia is defined by insufficient oxygen to tissues. In our case, we find the signs of mechanical asphyxia such as cyanosis and conjunctiva hemorrhage as well as histological elements like the alveolar edema and heterogeneous ventilation of the pulmonary parenchyma. This mechanism of asphyxia occurred when tensioning the ligature, by compression of the cervical vessels causing cerebral hypoxia and obstruction of the airways resulting in global asphyxia [1,19,22].

Based on the autopsy and histology findings, as well as the police investigation, the manner of death was determined to be a suicide and the cause of death was diagnosed as decapitation associated with an asphyxiation process by a mechanical origin. From the observations, it was postulated that the victim had attached a steel rope between his neck and a street light, after having passed the ligature through the left rear window, and then started his vehicle by blocking the accelerator. We subjected the assumption that when the vehicle has hitten the barrier, part of the kinetic energy accumulated at the time of acceleration has could be transferred to the obstacle. If the ligature used was not completely tended, it has could simulated strangulation and cause the mechanical asphyxia. The vehicle has continued its race, always accelerating and approaching a slope; the steel rope has ended up being completely tended and the force applied on the cervical region occasioned the complete decapitation. This findings are consistent with the date of literature in which the vehicle speed and slope steepness play a major role in the occurrence of asphyxia [1,22].

\section{Conclusion}

Decapitation is uncommon in forensic medicine. But this violent form of death can make it difficult to determine its origin. Although the context of discovery gives elements of orientation, it is the forensic pathologist that will play an essential role to determine the mechanism of death and the character (ante- or post-mortem) of decapitation. The most accurate documentation of the injuries characteristics in this kind of case therefore appears necessary.

\section{Declaration of interest: none}

\section{References}

[1] Zhao D, Ishikawa T, Quan L, Li D-R, Michiue T, Maeda H. Suicidal vehicle-assisted ligature strangulation resulting in complete decapitation: an autopsy report and a review of the literature. Leg Med (Tokyo). 2008 Nov;10(6):310-5. 
[2] Morild I, Lilleng PK. Different mechanisms of decapitation: three classic and one unique case history. J Forensic Sci. 2012 Nov;57(6):1659-64.

[3] Tsokos M, Türk EE, Uchigasaki S, Püschel K. Pathologic features of suicidal complete decapitations. Forensic Sci Int. 2004 Jan 28;139(2-3):95-102.

[4] Byard RW, Gilbert JD. Characteristic features of deaths due to decapitation. Am J Forensic Med Pathol. 2004 Jun;25(2):129-30.

[5] Zoja R, Battistini A, Gentile G. Death with complete decapitation: report of four suicides by train. Am J Forensic Med Pathol. 2009 Sep;30(3):303-6.

[6] Zhu B, Quan L, Ishida K, Oritani S, Taniguchi M, Fujita MQ, et al. Decapitation in suicidal hanging--a case report with a review of the literature. Leg Med (Tokyo). 2000 Oct;2(3):15962 .

[7] Hejna P, Bohnert M. Decapitation in suicidal hanging--vital reaction patterns. J Forensic Sci. 2013 Jan;58Suppl 1:S270-7.

[8] Töro K, Kristóf I, Keller E. Incomplete decapitation in suicidal hanging - report of a case and review of the literature. J Forensic Leg Med. 2008 Apr;15(3):180-4.

[9] Hejna P, Havel R. Vehicle-assisted decapitation: a case report. Am J Forensic Med Pathol. 2012 Mar;33(1):73-5.

[10] Rao D. An Autopsy Evaluation of Complete Decapitation Injuries. International Journal of Forensic Science \& Pathology. 2015 Apr;1:99-104.

[11] Nikolić V, Savić S, Antunović V, Marinković S, Andrieux C, Tomić I. Decapitation in reality and fine art: A review. Forensic Science International. 2017 Nov 1;280:103-12.

[12] Kumral B, Büyük Y, Gündogmus U.N, Sahin E, Sahin M.F. Medico-legal evaluation of deaths due to decapitation. Rom J Leg Med. 2012 Dec;20(4):251-4.

[13] Ausania F, Cittadini F, Cascini F, Polacco M, Pascali VL, Oliva A. Decapitation due to car accident. Am J Forensic Med Pathol. 2011 Dec;32(4):308-9.

[14] Kibayashi K, Yonemitsu K, Honjyo K, Tsunenari S. Accidental decapitation: an unusual injury to a passenger in a vehicle. Med Sci Law. 1999 Jan;39(1):82-4.

[15] Rautji R, Rudra A, Dixit V, Bhardwaj DN, Dogra TD. Decapitation in road traffic accident - a case report. Forensic Sci Int. 2003 Aug;135(3):237-8.

[16] Zoja R, Gentile G, Giovanetti GF, Palazzo E. Death by complete decapitation of motorcyclist wearing full face helmet: a case report. Forensic Sci Int. 2011 Apr;207(1-3):e4850. 
[17] Gioia S, Suadoni F, Carlini L, Lancia M, Bacci M. An unusual autopsy case of incomplete decapitation of a motorcyclist with herniation of thoracic organs through a helmet-related neck wound. Am J Forensic Med Pathol. 2013 Dec;34(4):325-7.

[18] Hejna P, Safr M, Zatopkova L. Suicidal decapitation by guillotine: case report and review of the literature. J Forensic Sci. 2012 Nov;57(6):192-4.

[19] Türk EE, Tsokos M. Vehicle-assisted suicide resulting in complete decapitation. Am J Forensic Med Pathol. 2005 Sep;26(3):292-3.

[20] Racette S, Vo TT, Sauvageau A. Suicidal decapitation using a tractor loader: a case report and review of the literature. J Forensic Sci. 2007 Jan;52(1):192-4.

[21] Samberkar PN. Motor vehicle-assisted ligature strangulation causing complete decapitation: an autopsy report. Am J Forensic Med Pathol. 2012 Mar;33(1):86-7.

[22] Barranco R, Caputo F, Bonsignore A, FraternaliOrcioni G, Ventura F. A Rare VehicleAssisted Ligature Hanging: Suicide at the Wheel. Am J Forensic Med Pathol. 2018 Mar;39(1):69-72.

[23] Subirana-Domènech M, Prunés-Galera E, Galdo-Ouro M. An uncommon suicide method : Self-strangulation by vehicle-assisted ligature ? Egyptian Journal of Forensic Sciences. 2014 Mar;4(1):21-24.

[24] Prichard PD. A suicide by self-decapitation. J Forensic Sci. 1993;38:981-4

[25] Byard RW, Gilbert JD. Cervical fracture, decapitation, and vehicle-assisted suicide. J Forensic Sci. 2002;47:392-4

[26] Dedouit F, Tournel G, Bécart A, Hédouin V, Gosset D. Suicidal hanging resulting in complete decapitation--forensic, radiological, and anthropological studies: a case report. J Forensic Sci. 2007 Sep;52(5):1190-3.

[27] Ihama Y, Miyazaki T, Fuke C, Niki H, Maehira T. Complete decapitation of a motorcycle driver due to a roadblock chain. Int J Legal Med. 2008 Nov;122(6):511-5.

[28] Osculati A, Visona SD, Della Chiesa L, Navarra F, Calbi A, Andrello L. Death due to decapitation in two motorcyclists: a description of a unique case and a brief review of the literature. J Forensic Sci. 2007 May;62(3):804-6.

[29] Buschmann C, Solarino B, Püschel K, Czubaiko F, Heinze S, Tsokos M. Post-mortem decapitation by domestic dogs: three case reports and review of the literature. Forensic Sci Med Pathol. 2011 Apr;7(4):344-9. 

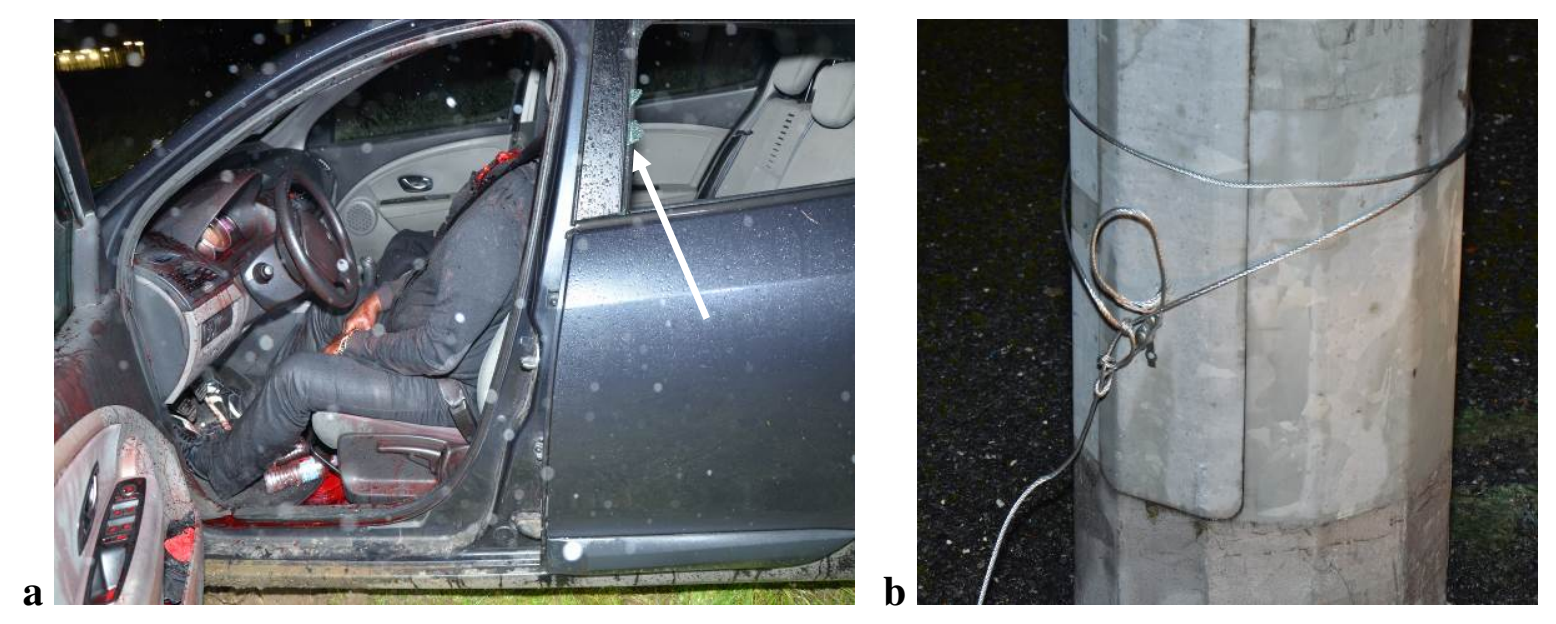

Figure 1: (a) Decapitated human body sitting on the driver's side of a vehicle, the left rear window broken (white arrow), with great amount of blood in the vehicle; (b) a steel rope, of a diameter 0,5 centimeters, attached to a street light. 

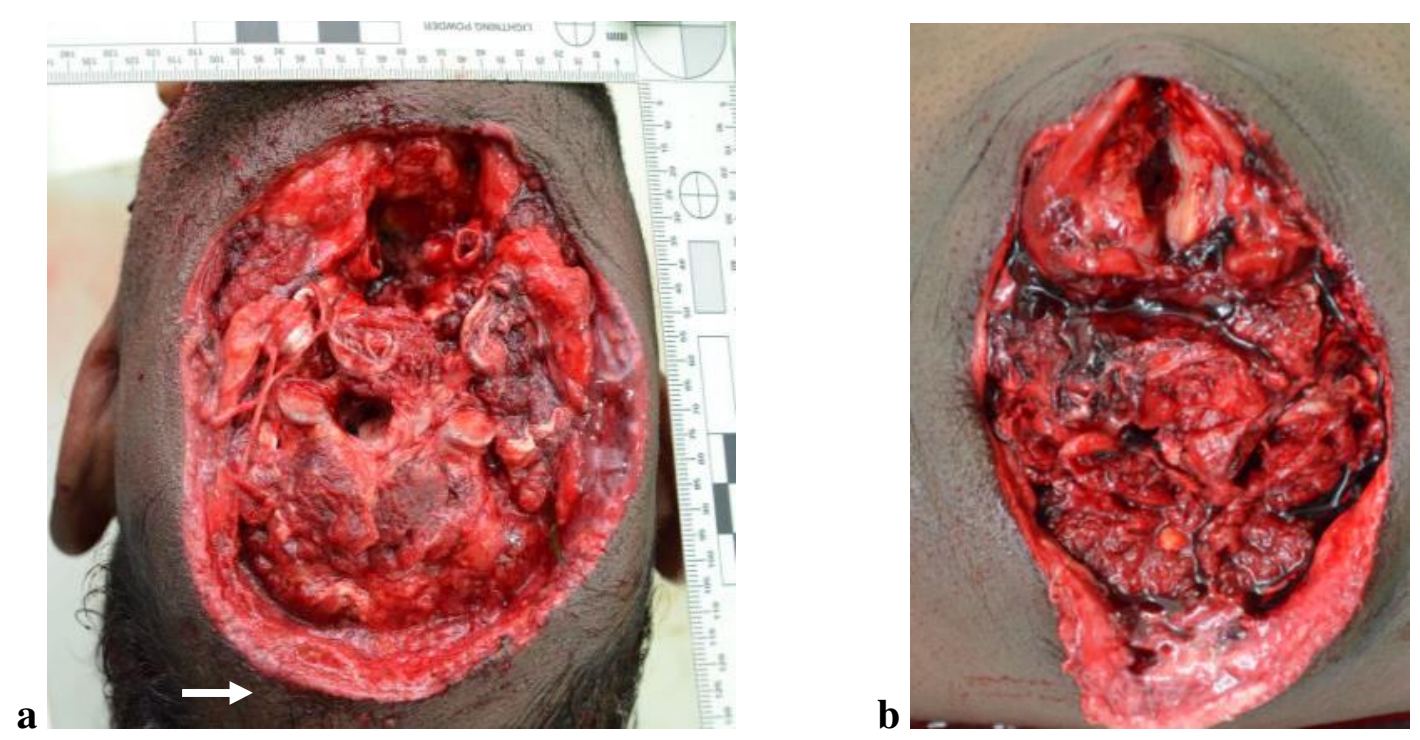

Figure 2: (a) Separated head show a clear-cut and a hemorrhagic infiltration of edges, slightly abraded at its rear part of the neck (white arrow); (b) Separated body reveal a diffuse hemorrhagic infiltration of the cervical region of the severance level. 

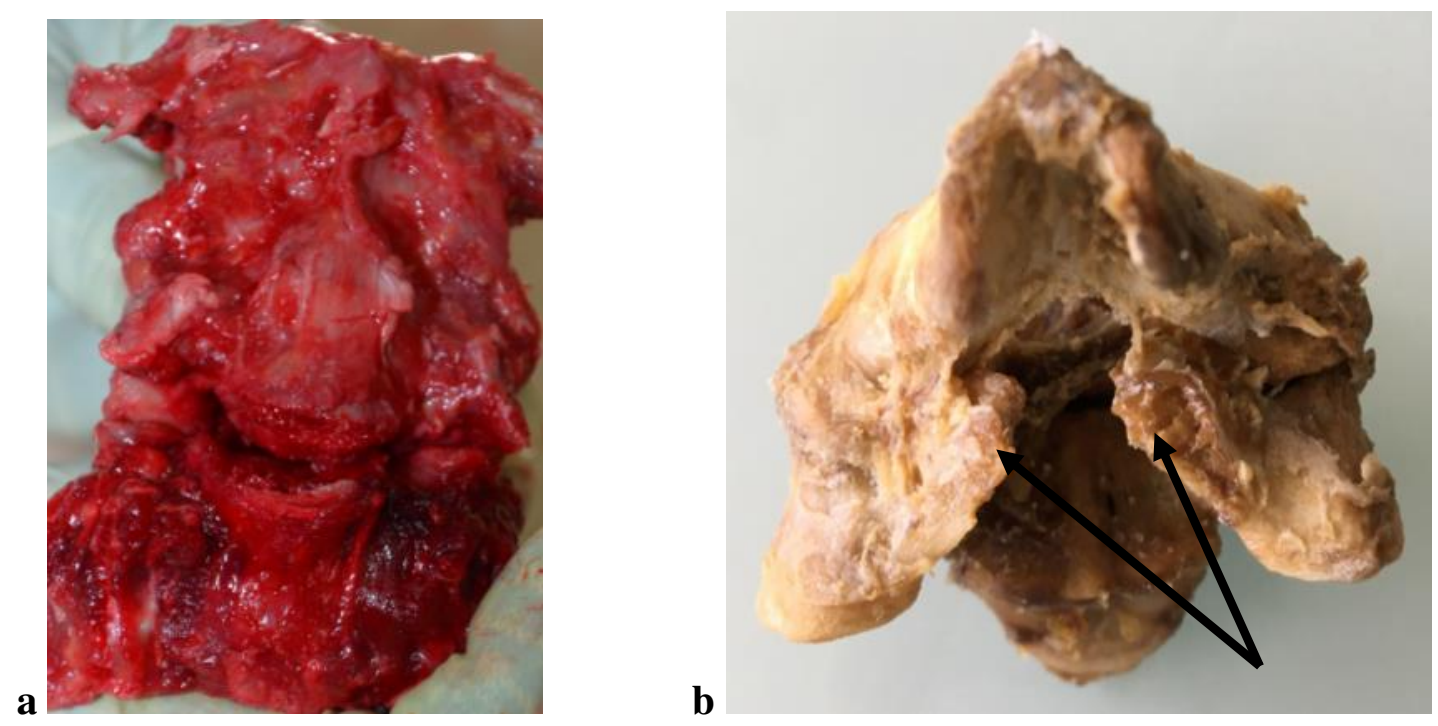

Figure 3: (a) severance plane pass through the third intervertebral disc. After an edge-to-edge, both parts of the cervical spine were perfectly articulated; (b) on the third cervical vertebra, the spinous process is fractured (black arrows). 

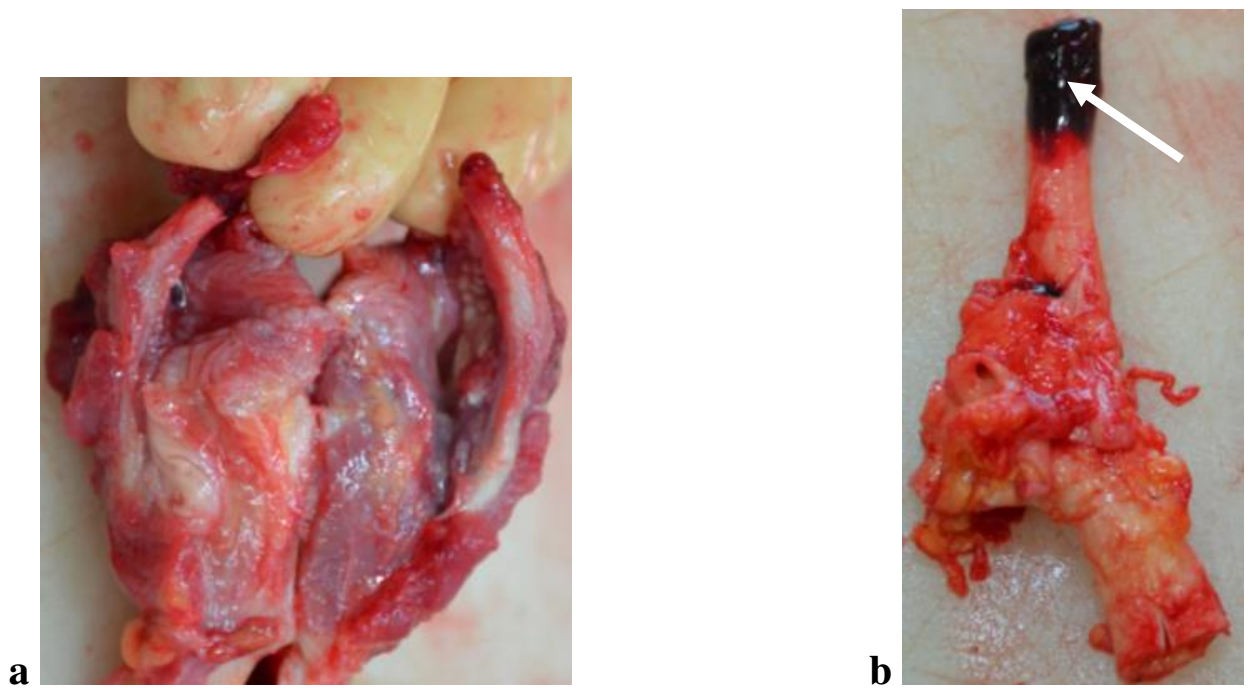

Figure 4: (a) The left upper horn of the thyroid cartilage is completely cut; (b) the carotid arteries are sectioned, with peripheral hemorrhagic infiltration. 
Table 1

A review of the literature on decapitation by vehicle-assisted ligature strangulation

\begin{tabular}{|c|c|c|c|c|c|}
\hline Case no. & $\begin{array}{l}\text { Gender, } \\
\text { age (years) }\end{array}$ & $\begin{array}{l}\text { Ligature (material, length and width, } \\
\text { stationary object tied to) }\end{array}$ & Lesions of the neck & Other pathological findings & Ref. \\
\hline $\begin{array}{l}1 \quad(1993, \\
\text { UK) }\end{array}$ & Male, 28 & $\begin{array}{l}\text { Nylon, } 5 / 8 \text { inch wide and } 25 \mathrm{ft} \text { long, } \\
\text { tree sump }\end{array}$ & $\begin{array}{l}\text { A sharply defined wound similar to that administered } \\
\text { by a guillotine. Complete decapitation }\end{array}$ & $\mathrm{a}$ & [24] \\
\hline $\begin{array}{l}2 \quad(2002, \\
\text { Australia) }\end{array}$ & Male, 24 & $\begin{array}{l}\text { Rope, a stationary post } 80 \mathrm{~m} \text { away } \\
\text { from the car }\end{array}$ & $\begin{array}{l}\text { A parchmented ligature mark around the neck. } \\
\text { Separation of the hyoid bone from the thyroid cartilage } \\
\text { with fractures of both. Transection of the right } \\
\text { common carotid artery and lower pharynx. } \\
\text { Incomplete decapitation }\end{array}$ & a & [25] \\
\hline $\begin{array}{l}3 \text { (2005, } \\
\text { Germany) }\end{array}$ & Male, 43 & Metal, $40 \mathrm{~m}$ long, fence & $\begin{array}{l}\text { Clear-cut wound edges with an adjacent sharply } \\
\text { demarcated abrasion. Severance plane was above the } \\
\text { larynx. Complete decapitation }\end{array}$ & a & [19] \\
\hline $\begin{array}{l}4 \quad(2008, \\
\text { Japan })\end{array}$ & Male, 59 & $\begin{array}{l}\text { Double-twisted hemp, } 10 \mathrm{~m} \text { long and } \\
1 \mathrm{~cm} \text { wide, cherry tree }\end{array}$ & $\begin{array}{l}\text { Clear-cut wound edges with a peripheral abrasion. } \\
\text { Severance line between the second and third cervical } \\
\text { vertebrae. Fractures of thyroid cartilage. } \\
\text { Complete decapitation }\end{array}$ & $\begin{array}{l}\text { Congested face. Marked brain swelling with } \\
\text { edema and congestion. Slightly congested } \\
\text { lungs. Pale and bloodless appearance of other } \\
\text { organs }\end{array}$ & [1] \\
\hline $\begin{array}{l}5 \quad(2012, \\
\text { Norway) }\end{array}$ & Male, ${ }^{\text {a }}$ & $\begin{array}{l}\text { Nylon, } 28 \mathrm{~m} \text { long and } 0,7 \mathrm{~cm} \text { wide, } \\
\text { light post }\end{array}$ & $\begin{array}{l}\text { Clear-cut wound edges with a ligature mark. Severance } \\
\text { plane between the third and fourth cervical vertebrae. } \\
\text { Upper horns of the thyroid cartilage, and the hyoid } \\
\text { bone were fractured. Complete decapitation }\end{array}$ & 复 & [2] \\
\hline $\begin{array}{l}6 \text { (2012, } \\
\text { Malaysia) }\end{array}$ & Male, 63 & $\begin{array}{l}\text { Nylon, front iron gate of house } 60 \mathrm{~m} \\
\text { away from the car }\end{array}$ & $\begin{array}{l}\text { Clear-cut wound edges with abrasions. One third of the } \\
\text { larynx attached to the head }\end{array}$ & Congested face and tongue bite & [21] \\
\hline $\begin{array}{l}7 \quad(2018, \\
\text { France })\end{array}$ & Male, 43 & $\begin{array}{l}\text { Steel, } 0,5 \mathrm{~cm} \text { wide, a light street } 100 \\
\mathrm{~m} \text { away from the car }\end{array}$ & $\begin{array}{l}\text { Clear-cut wound edges with hemorrhagic infiltration } \\
\text { and abrasions. Severance plane between the third and } \\
\text { fourth cervical vertebrae. Upper left horn of thyroid } \\
\text { cartilage is sectioned. Section of carotid artery with } \\
\text { hemorrhagic infiltration. Complete decapitation }\end{array}$ & $\begin{array}{l}\text { Lungs and brain are edematous and } \\
\text { congestive. Pale and bloodless appearance of } \\
\text { other organs. Blood in trachea and bronchi. }\end{array}$ & $\begin{array}{l}\text { Our } \\
\text { case }\end{array}$ \\
\hline
\end{tabular}

\footnotetext{
${ }^{\mathrm{a}}$ Absence of descriptions
} 
Table 2

Morphological features of decapitation lesions in ligature suicides and stabbing homicides

\begin{tabular}{|c|c|c|c|}
\hline \multicolumn{4}{|c|}{ Clear-cut and hemorrhagic infiltration of edges } \\
\hline & \multicolumn{2}{|c|}{ Peripheral abrasion } & No abrasion \\
\hline Severance plane & Third and fourth cervical vertebrae & \multicolumn{2}{|c|}{ First and second or second and third cervical vertebrae } \\
\hline
\end{tabular}

